\title{
MEASURING SERVICE QUALITY IN HOSPITALITY ON THE BASIS OF USER PERCEPTIONS: ACASE STUDY OF PALIĆ
}

\section{Dragan Vojinović ${ }^{1}$ Ljubiša Vladušić 1 , Milena Mirković}

\author{
1 University of East Sarajevo, \\ Faculty of Economics, \\ Pale, Bosnia and Herzegovina \\ ${ }^{2}$ University of East Sarajevo, \\ Faculty of Education in Bijeljina, \\ Bijeljina, Bosnia and Herzegovina.
}

\begin{abstract}
:
Taking into account the basic characteristics and peculiarities of the service sector, and the importance of hotel business as a tourism industry segment, the paper presents research results of measuring the quality of services in the hotel industry in the area of tourism facilities, based on the perceived customer satisfaction, through the methods of SERVQUAL. Hotel services are the crucial tourism segment, which is becoming dominant in defining the values in economic and public life and its development, and is based on the needs of consumers to meet their needs for rest, recreation, adventure, improving health status, religion, education, business arrangements etc. The quality of service is the basic measure of consumer satisfaction or dissatisfaction. This research aims to analyze the perceived value of services offered and expectations of the impact on the perceived quality. Empirical research was conducted in the area of the tourist complex Palić.
\end{abstract}

Keywords:

expectations, hotel services, model, quality perception.

\section{INTRODUCTION}

It is not necessary to particularly underline the role and importance of the service sector, especially tourism, in economic trends, both locally and globally. Tourism, with its components, lodging and catering services, through direct and indirect action in all economic processes, has a function of an engine of development and basic values of economic and public life. The study of the phenomenon of tourism began "later" compared to other industries, but today is a system that is clearly determined theoretically, practically proven and subject to the interests of individuals, businesses and the wider community. The recessive trends, and the economic crisis, the possibilities of the tourism industry, with all its specifics, are the basic mechanism, not only for the local development, but also their involvement in the global markets.

Global economic trends and integrated processes, which are incorporated in all spheres of economic and social life, do not allow national economies autarchy, they force them to change the business, but at the same time, give them a chance to find themselves here. For instance, CEFTA agreement was signed in 2006 under the auspices of the European Union, as the largest verified regional organization in the neighborhood of the Republic of Serbia.
Correspondence:

Milena Mirković

e-mail:

mirkovic.milena@yahoo.com 
Travel markets in the Republic of Serbia, and thus the tourist facilities, are more advanced and developed, observing quantitative and qualitative indicators. This discrepancy compared to other tourism markets should be accepted as a signal for concrete action to increase the competitive advantages of tourism entities, and therefore a tourism destination. Tourism constitutes the basis for the realistic, sustainable development of the economy of the Republic of Serbia and is based on the use of the products and services of foreign and domestic tourists / guests. Defining the concept of foreign or domestic guest must be analyzed in the procedural approach, and in the market, and marketing orientation, we must equalize them through the prism of service operations to be responsive to their needs and motives of delivering superior value and total quality.

A guest, visitor, consumer represents the formal and essential meaning of existence the hospitality, and balance sheet items of institutions the maximum value of their assets. Observed statistically, one customer to the institution is not a condition of its existence, but we have to say that there are no institutions without a guest.

Competitive advantages sensed data on the number of visits and duration of stay in a particular area, and in defined locations, built on the attitudes of individuals, or through their perception of quality of experienced services. It has been said that the power of consumer bet on the quality of hotel and catering services and tourism enterprise determines its market position. The level of service is not only the factor of success and survival of the tourism sector, but the basis for its further sustainable development. The quality of services, viewed from the technical, functional and communication aspect is the care of the guest. The quality of service determines the customer satisfaction, which directly reflects on establishing and maintaining long-term relationships with them, and indirectly, it reflects the expectations of others, potential customers through their mutual communication, propaganda or "word of mouth", no matter if it is positively or negatively oriented.

\section{MEASURING THE QUALITY OF SERVICES}

In order to measure the quality of services, a modified "SERVQUAL" model has been used, with an emphasis on the importance of the communication process between the tourist companies, or employees and guests. Research and testing of expectations and perceptions of survivorship services in hotel business and catering by consumers was conducted within a tourist complex Palić. Selecting this place caused the existence of natural and created the capacity for the provision of services, achieved level of development, but we have to mention the underutilized features. According to Tanjug as of October 26, 2015, an important factor was the allocation of representatives Palić, by the jury of the international association of tourism journalists FIJET, awards "The Golden Apple" as the number one destination in Serbia. In addition, Palić laureates were Moscow and Dubrovnik.

The technical and functional quality of services as well as the basic determinants of customer care point to the undoubted importance of the communication aspect. Measuring service quality in theoretical considerations and practical research has indicated certain problems, which stem from the characteristics and nature of services and the specifics of the tourism market (Kotler \& Keller, 2009). According to Beateson and Hoffman (2012), "quality of service is not the goal or program that can be achieved or met, but it must be an integral part of the whole process of daily management and service delivery. In the end, the quality of services is both art and science."

The quality of delivered services is becoming the backbone of the organizational and functional efforts of the tourism industry achieved through satisfactioncustomer satisfaction. The consumer is satisfied when their expectations are in line with their needs, desires, problems and demands, and this condition can lead to the habit of re-purchase of the product or using the service. The quality should be observed regarding certain components, customer satisfaction, expressed by the concordance level between the expected and experienced (Kosar \& Rašeta, 2005). Customer satisfaction is typically defined as a post consumption evaluative judgement concerning a specific product or service (Gundersen et al., 1996).

In the long term, sustainable level of quality of services in totality competitive relations or the fight for the customer represents the strongest and most effective weapon. This can be seen through the function of hotel business, care of the guest or guests' notion as "king". The level of customer satisfaction achieved is adequate to the totality of all business activities in terms of satisfying its needs. Choi and Chu concluded that the staff quality, room qualities and value are the top three factors that determine travelers satisfaction. Increasing competition in the tourism industry greatly affects he performance of particular tourist operators and leads to personalization of services. Products or services marketed by different suppliers basically have similar or the same use-value in the process of creating a different 
experience for guests. Moreover, perceiving the needs and desires of customers, is the most difficult task in the hotel and catering industry.

The quality of service experienced by the guest encompasses both material and personal aspect, and they create its expected service value individually (Ćosić, 2006). The material aspect of service quality is reflected through the senses of human beings and is represented by the physical attributes of the object and the environment, exterior and interior design, decorations, regular room, staff appearance, taste and smell of food etc. Personal aspect relates to intangible elements such as the way of receiving guests, the ratio of employees through their kindness, empathy, expertise, verbal and non-verbal communication skills and the totality of the activities of all components of service culture. The preference for material or personal aspect in achieving an adequate level of service quality would be wrong. Their synergy effect through their interconnectedness, understanding, tolerance and cooperative relationship in the creation and delivery of services should be greater than the sum of the effect of certain aspects. Zeithaml and Bitner (2003) stated that in order to manage service quality, it was important to manage the gaps between expectations and perceptions on the part of management, employers and customers.

The development of business relations, the intensity of competition in the supply chain, changes in attitudes of guests, technological advances leading to the formation of a certain standard and unification of standards of service quality. Differentiating from other becomes an imperative in the fight for market share. According to Porter (2007), one way of achieving this goal is differentiation that is "the result of specific activities that company performs and their impact on customers." In this respect, communication provides most opportunities for this.

Communication is basically a process of transferring information from the sender to the recipient and is often identified with promotional activities. In the hotel and catering, broadcasting and receiving information is not the ultimate goal. The complexity of relationships in this industry opens a wide range of effects of all forms of communication in the present and future time. "For managers, the challenge is to go beyond the surface of the thin smiling receptionist or looks brand and ensure that the elusive quality of service you would like more and more customers and that more were expected" (Moutinho, 2005). Strong competitive relations, technological innovation, uncertainty and business risk, radical change in attitudes of guests, the necessity of growth and development, shorter life span of products and services required, speed of decision making and the creative, efficient and appropriate concept of two-way communication.

Communication in all its forms, in relationships of all participants should be based on knowledge, training, and skills through the art of transmitting messages and responses by the employees. The aspect of communication follows the development of technology. However, it must not ignore the impact of social networks, which represent a golden opportunity for the tourism and hotel industry, opening the possibility of a strong and direct contact with clients.

\section{RESEARCH METHODOLOGY}

Research on the attitudes of clients towards the quality of hotel and catering services in a tourism complex Palić is based on the application of "SERVQUAL", as a basic tool for the evaluation of the quality of services in the marketing literature for the services sector. This model treats the five determinants of quality, tangibles, reliability, responsibility, security and compassion through 22 pairs of Likert scale in relation to the expected and perceived customer satisfaction. Going into deeper analysis of the models and confirmation or denial of the application of its efficiency in the past period and the current agenda modifies our goal to define the quality of service, thus emphasizing the communication aspect. Although there are studies on measuring the quality of services in the hotel and catering industry based on the original "SERVQUAL" model, this research should make a contribution to the literature by defining the role of the communication aspect in achieving customer satisfaction. As already mentioned, the main aim of the research is to measure the quality of services, and verification of the model "SERVQUAL" developed by Parasuraman, Zeithaml and Bery. The purpose of measuring the quality of service is ascertainment the current status and level of quality and deviations of perceived quality than offered.

Based on this model and when the difference between perceived and expected is zero, it indicates the necessity to fulfill guests' expectations. The deviation up or down, or the negative or positive difference, talk about the delivery of services or higher value implies poor quality of services.

Field research in the area of tourism facilities was based on the primary data collection using the interrogative techniques by means of surveys. A questionnaire determined by the assessment of the scale Likert 
attitudes of respondents from 5 value was used as a primary research tool, starting from 1 (strongly disagree) to 5 (total agreement). The questionnaire consists of two parts that are structured on the basis of 22 questions, where the first part refers to the expectations, and the second part to the perception of the quality of the guests. The questionnaire consists of three dimensions of quality, arranged according to the principle of the original “SERVQUAL" model.

The aim of the research is to determine the dimensions of service quality in tourism and hospitality, and whether there are differences in the guest expectations in comparison to the "promised" and actual quality of service.

\section{RESULTS}

This research covered a sample of 55 respondents. Out of the total number, 75\% were domestic and 25\% foreign guests, 53\% were men and 47\% women. According to the age of respondents, $36 \%$ aged 30 years, $18 \%$ aged $30-40$ years, $18 \%$ aged $40-50$ years, $15 \%$ aged $50-60$ years and $13 \%$ have 60 or more years.

In order to determine the difference between expectations and perceptions, we used the t-test of independent samples to compare the means of the results and determine the statistical significance of their differences. In our case, $\mathrm{t}$ - test was used to compare the arithmetic mean of two groups in terms of expectations and perceptions.

Table 1. Dimensions and quality issues to be assessed for the achieved level of customer satisfaction

\begin{tabular}{|c|c|c|}
\hline 1. & $\begin{array}{l}\text { The location of the hotel and the restaurant should be affordable, with appropriate } \\
\text { approaches and parking }\end{array}$ & $1 \ldots 2 \ldots 3 \ldots 4 \ldots 5$ \\
\hline 2. & $\begin{array}{l}\text { Exterior of the premises and the environment should be visually appealing with clearly } \\
\text { prominent promotional tools }\end{array}$ & $1 \ldots 2 \ldots 3 \ldots 4 \ldots 5$ \\
\hline 3. & $\begin{array}{l}\text { The interior of the hotel and restaurant should be visually appealing, with a suitable } \\
\text { arrangement of the rooms, neat and modern }\end{array}$ & $1 \ldots 2 \ldots 3 \ldots 4 \ldots 5$ \\
\hline 4. & Employees should be uniform and tidy & $1 \ldots 2 \ldots 3 \ldots 4 \ldots 5$ \\
\hline 5. & Hotel and restaurant should offer service at the agreed time & $1 \ldots 2 \ldots 3 \ldots 4 \ldots 5$ \\
\hline 6. & Employees should be always ready to help the guests & $1 \ldots 2 \ldots 3 \ldots 4 \ldots 5$ \\
\hline 7. & Guests need to feel safe and secure & $1 \ldots 2 \ldots 3 \ldots 4 \ldots 5$ \\
\hline 8. & Employees need to understand the specific needs of its guests & $1 \ldots 2 \ldots 3 \ldots 4 \ldots 5$ \\
\hline 9. & The provision of services should be performed without errors & $1 \ldots 2 \ldots 3 \ldots 4 \ldots 5$ \\
\hline 10. & The range of services should meet the needs of guests & $1 \ldots 2 \ldots 3 \ldots 4 \ldots 5$ \\
\hline 11. & Stay in the hotel and restaurant should be an unforgettable experience & $1 \ldots 2 \ldots 3 \ldots 4 \ldots 5$ \\
\hline 12. & Employees need to invest additional effort to interact with guests & $1 \ldots 2 \ldots 3 \ldots 4 \ldots 5$ \\
\hline 13. & Cozy and friendly atmosphere should rule in hotels and restaurants & $1 \ldots 2 \ldots 3 \ldots 4 \ldots 5$ \\
\hline 14. & Employees should be always present in addition to providing unobtrusive service & \\
\hline 15. & $\begin{array}{l}\text { The first impression of the hotel and restaurant should leave a strong, positive } \\
\text { impression }\end{array}$ & $1 \ldots 2 \ldots 3 \ldots 4 \ldots 5$ \\
\hline 16. & Employees should have the communication skills & $1 \ldots 2 \ldots 3 \ldots 4 \ldots 5$ \\
\hline 17. & Objection guests will immediately be accepted and resolved in the shortest possible time & $1 \ldots 2 \ldots 3 \ldots 4 \ldots 5$ \\
\hline 18. & $\begin{array}{l}\text { Employees should respect the principle of social structures (different genders, class, } \\
\text { religion, age) }\end{array}$ & $1 \ldots 2 \ldots 3 \ldots 4 \ldots 5$ \\
\hline 19. & Verbal and non-verbal communication should be efficient & $1 \ldots 2 \ldots 3 \ldots 4 \ldots 5$ \\
\hline 20. & Hotel and restaurant services should always be provided with the same level of quality & $1 \ldots 2 \ldots 3 \ldots 4 \ldots 5$ \\
\hline 21. & On request should be given a timely, specific and accurate answer & $1 \ldots 2 \ldots 3 \ldots 4 \ldots 5$ \\
\hline 22. & When departure should be addressed appreciation for the use of services & $1 \ldots 2 \ldots 3 \ldots 4 \ldots 5$ \\
\hline
\end{tabular}


Table 2. T-Test for independent samples expectation and perception

\begin{tabular}{|c|c|c|c|c|c|}
\hline \multicolumn{2}{|c|}{ DETERMINANTS OF QUALITY } & $\mathrm{AM}$ & SD & T-test & $\mathrm{P}$ \\
\hline \multirow{12}{*}{ TANGIBLES } & Expectations 1 & 4,4545 & 0,878 & \multirow{2}{*}{0,600} & \multirow{2}{*}{0,551} \\
\hline & Perceptions 1 & 4.3818 & 0,7326 & & \\
\hline & Expectations 2 & 4,1091 & 0,91637 & \multirow{2}{*}{0,617} & \multirow{2}{*}{0,540} \\
\hline & Perceptions 2 & 4,0182 & 0,84964 & & \\
\hline & Expectations 3 & 4,2182 & 0,80946 & \multirow{2}{*}{0,724} & \multirow{2}{*}{0,472} \\
\hline & Perceptions 3 & 4,1091 & 0,85359 & & \\
\hline & Expectations 4 & 4,3636 & 1,04285 & \multirow{2}{*}{1,016} & \multirow{2}{*}{0,314} \\
\hline & Perceptions 4 & 4,2182 & 0,8754 & & \\
\hline & Expectations 5 & 4,709 & 0,5667 & \multirow{2}{*}{3,839} & \multirow{2}{*}{0,000} \\
\hline & Perceptions 5 & 4,254 & 0,8214 & & \\
\hline & Expectations 6 & 4,60 & 0,56437 & \multirow{2}{*}{2,899} & \multirow{2}{*}{0,005} \\
\hline & Perceptions 6 & 4,236 & 0,7444 & & \\
\hline \multirow{12}{*}{ RELIABILITY } & Expectations 7 & 4,800 & 0,5252 & \multirow{2}{*}{3,782} & \multirow{2}{*}{0,000} \\
\hline & Perceptions 7 & 4,3636 & 0,75434 & & \\
\hline & Expectations 8 & 4,0545 & 1,0957 & \multirow{2}{*}{1,759} & \multirow{2}{*}{0,084} \\
\hline & Perceptions 8 & 3,7455 & 0,9273 & & \\
\hline & Expectations 9 & 4,099 & 0,94815 & \multirow{2}{*}{1,790} & \multirow{2}{*}{0,079} \\
\hline & Perceptions 9 & 3,8182 & 0,92478 & & \\
\hline & Expectations 10 & 4,2909 & .68510 & \multirow{2}{*}{2,257} & \multirow{2}{*}{0,028} \\
\hline & Perceptions 10 & 4,000 & .72008 & & \\
\hline & Expectations 11 & 3,6727 & 1.05505 & \multirow{2}{*}{0,574} & 0.568 \\
\hline & Perceptions 11 & 3,600 & 1.08184 & & 0,568 \\
\hline & Expectations 12 & 3,600 & .97373 & 0000 & 1000 \\
\hline & Perceptions 12 & 3,600 & .99256 & 0,000 & 1,000 \\
\hline & Expectations 13 & 4,4182 & .83202 & 1197 & 0237 \\
\hline & Perceptions 13 & 4.2545 & .72567 & 1,191 & 0,231 \\
\hline & Expectations 14 & 3.8364 & 1.06742 & 0739 & 0.463 \\
\hline & Perceptions 14 & 3.7091 & .99392 & 0,139 & 0,463 \\
\hline & Expectations 15 & 4.2364 & .83807 & 1211 & 0231 \\
\hline & Perceptions 15 & 4.0909 & .84487 & 1,211 & 0,251 \\
\hline & Expectations 16 & 4.4000 & .70972 & 3,396 & 0,001 \\
\hline & Perceptions 16 & 4.0000 & .86066 & & \\
\hline & Expectations 17 & 4,3273 & 0,74671 & 0.617 & 0.540 \\
\hline COMMUNICATION & Perceptions 17 & 4,2364 & 0,85988 & $0,01 /$ & 0,540 \\
\hline COMIVIUNICATION & Expectations 18 & 4,2182 & 1,16573 & 0.531 & 0.508 \\
\hline & Perceptions 18 & 4,1455 & 1,00771 & 0,501 & $0,5>0$ \\
\hline & Expectations 19 & 4,3273 & 0,81773 & 2607 & 0012 \\
\hline & Perceptions 19 & 4,0182 & 0,89217 & $2,00 /$ & 0,012 \\
\hline & Expectations 20 & 4,4545 & 0,81236 & 3334 & 0,002 \\
\hline & Perceptions 20 & 3,9818 & 0,80487 & 3,534 & 0,002 \\
\hline & Expectations 21 & 4,600 & 0,70972 & 4020 & 0000 \\
\hline & Perceptions 21 & 4,0182 & 0,9524 & 4,929 & 0,000 \\
\hline & Expectations 22 & 4,5818 & 0,91674 & 1277 & 0207 \\
\hline & Perceptions 22 & 4,3818 & 0,9524 & $1,2 / 1$ & 0,201 \\
\hline
\end{tabular}

Source: Results of the research of the author

Based on the results in Table 1, it can be concluded that there are significant differences in expectations and perceptions of determinants.

As regards quality determinants, TANGIBILITY test shows that there is a statistically significant difference in test pairs O1-P1, P2-O2, O3 and O4-P3-P4 while it cannot be observed for the other pairs. In the case of the determinants of RELIABILITY, there is a statistically significant difference in test pairs O8-P8, P9-O9, O11 and O12-P11-P12. Finally, as regards COMMUNICATION determinants, statistically significant difference exists in the tested pairs O13-P13, P14-O14, O15 and O17-P15-P17, P18 and A18-022-P22, while it cannot be observed in other pairs.

This can be seen if we observe the descriptive statistics for the expectations and perceptions of determinants. 
Table 1. Descriptive statistics for P0-P5

\begin{tabular}{lcccccccccc}
\hline & $\mathrm{P} 0$ & $\mathrm{P} 1$ & $\mathrm{O} 2$ & $\mathrm{P} 2$ & $\mathrm{O} 3$ & $\mathrm{P} 3$ & $\mathrm{O} 4$ & $\mathrm{P} 4$ & O5 & P5 \\
\hline Mean & 4.4545 & 4.3818 & 4.1091 & 4.0182 & 4.2182 & 4.1091 & 4.3636 & 4.2182 & 4.7091 & 4.2545 \\
\hline Median & 5.0000 & 5.0000 & 4.0000 & 4.0000 & 4.0000 & 4.0000 & 5.0000 & 4.0000 & 5.0000 & 4.0000 \\
\hline Mode & 5.00 & 5.00 & 5.00 & $4.00^{\mathrm{a}}$ & 5.00 & $4.00^{\mathrm{a}}$ & 5.00 & 5.00 & 5.00 & 5.00 \\
\hline Std. deviation & .87809 & .73260 & .91637 & .84964 & .80946 & .85359 & 1.04285 & .87540 & .56676 & .82143 \\
\hline Rate asymmetry & -.559 & -.839 & -.722 & -.223 & -.642 & -.585 & -.605 & -.764 & -.848 & -.827 \\
\hline $\begin{array}{l}\text { A standard error } \\
\text { of asymmetry }\end{array}$ & .322 & .322 & .322 & .322 & .322 & .322 & .322 & .322 & .322 & .322 \\
\hline Measure flatness & 1.523 & .774 & -.089 & -1.131 & -.511 & -.467 & 1.659 & .259 & 2.528 & .318 \\
\hline $\begin{array}{l}\text { A standard error } \\
\text { of flatness }\end{array}$ & .634 & .634 & .634 & .634 & .634 & .634 & .634 & .634 & .634 & .634 \\
\hline Minimum & 2.00 & 2.00 & 2.00 & 2.00 & 2.00 & 2.00 & 1.00 & 2.00 & 3.00 & 2.00 \\
\hline Maximum & 5.00 & 5.00 & 5.00 & 5.00 & 5.00 & 5.00 & 5.00 & 5.00 & 5.00 & 5.00 \\
\hline
\end{tabular}

Table 2. Descriptive statistics for O6-P10

\begin{tabular}{lcccccccccc}
\hline & O6 & P6 & O7 & P7 & O8 & P8 & O9 & P9 & O10 & P10 \\
\hline Mean & 4.6000 & 4.2364 & 4.8000 & 4.3636 & 4.0545 & 3.7455 & 4.0909 & 3.8182 & 4.2909 & 4.0000 \\
\hline Median & 5.0000 & 4.0000 & 5.0000 & 5.0000 & 4.0000 & 4.0000 & 4.0000 & 4.0000 & 4.0000 & 4.0000 \\
\hline Mode & 5.00 & 5.00 & 5.00 & 5.00 & 5.00 & 4.00 & 5.00 & 3.00 & 4.00 & 4.00 \\
\hline Std. deviation & .56437 & .74445 & .52352 & .75434 & 1.09575 & .92733 & .94815 & .92478 & .68510 & .72008 \\
\hline Rate asymmetry & -.852 & -.417 & -3.439 & -.724 & -.851 & -.618 & -.863 & -.352 & -.447 & -.618 \\
\hline $\begin{array}{l}\text { A standard error } \\
\text { of asymmetry }\end{array}$ & .322 & .322 & .322 & .322 & .322 & .322 & .322 & .322 & .322 & .322 \\
\hline Measure flatness & .158 & -1.068 & 4.683 & -.862 & 1.284 & .341 & .526 & .002 & -.785 & .829 \\
\hline $\begin{array}{l}\text { A standard error } \\
\text { of flatness }\end{array}$ & .634 & .634 & .634 & .634 & .634 & .634 & .634 & .634 & .634 & .634 \\
\hline Minimum & 3.00 & 3.00 & 2.00 & 3.00 & 1.00 & 1.00 & 1.00 & 1.00 & 3.00 & 2.00 \\
\hline Maximum & 5.00 & 5.00 & 5.00 & 5.00 & 5.00 & 5.00 & 5.00 & 5.00 & 5.00 & 5.00 \\
\hline
\end{tabular}

Table 3. Descriptive statistics for O11-P15

\begin{tabular}{|c|c|c|c|c|c|c|c|c|c|c|}
\hline & O11 & P11 & O12 & $\mathrm{P} 12$ & $\mathrm{O} 13$ & $\mathrm{P} 13$ & O14 & $\mathrm{P} 14$ & O15 & P15 \\
\hline Mean & 3.6727 & 3.6000 & 3.6000 & 3.6000 & 4.4182 & 4.2545 & 3.8364 & 3.7091 & 4.2364 & 4.0909 \\
\hline Median & 4.0000 & 4.0000 & 4.0000 & 4.0000 & 5.0000 & 4.0000 & 4.0000 & 4.0000 & 4.0000 & 4.0000 \\
\hline Mode & 4.00 & 4.00 & 4.00 & 4.00 & 5.00 & 4.00 & 4.00 & 4.00 & 5.00 & 4.00 \\
\hline Std. deviation & 1.05505 & 1.08184 & .97373 & .99256 & .83202 & .72567 & 1.0674 & .99392 & .83807 & .84487 \\
\hline Rate asymmetry & -.770 & -.769 & -.729 & -.288 & -1.932 & -.735 & -.894 & -.667 & -.869 & -.559 \\
\hline $\begin{array}{l}\text { A standard error } \\
\text { of asymmetry }\end{array}$ & .322 & .322 & .322 & .322 & .322 & .322 & .322 & .322 & .322 & .322 \\
\hline Measure flatness & .453 & .465 & .449 & -.400 & 1.901 & .378 & .334 & .449 & .068 & -.434 \\
\hline $\begin{array}{l}\text { A standard error } \\
\text { of flatness }\end{array}$ & .634 & .634 & .634 & .634 & .634 & .634 & .634 & .634 & .634 & .634 \\
\hline Minimum & 1.00 & 1.00 & 1.00 & 1.00 & 1.00 & 2.00 & 1.00 & 1.00 & 2.00 & 2.00 \\
\hline Maximum & 5.00 & 5.00 & 5.00 & 5.00 & 5.00 & 5.00 & 5.00 & 5.00 & 5.00 & 5.00 \\
\hline
\end{tabular}


Table 4. Descriptive statistics for O16-O19

\begin{tabular}{|c|c|c|c|c|c|c|c|}
\hline & $\mathrm{O} 16$ & P16 & O17 & P17 & $\mathrm{O} 18$ & P18 & O19 \\
\hline Mean & 4.4000 & 4.0000 & 4.3273 & 4.2364 & 4.2182 & 4.1455 & 4.3273 \\
\hline Median & 5.0000 & 4.0000 & 4.0000 & 4.0000 & 5.0000 & 4.0000 & 5.0000 \\
\hline Mode & 5.00 & 4.00 & 5.00 & 5.00 & 5.00 & 5.00 & 5.00 \\
\hline Std. deviation & .70972 & .86066 & .74671 & .85988 & 1.16573 & 1.00771 & .81773 \\
\hline Rate asymmetry & -.761 & -.904 & -.900 & -1.392 & -.609 & -.429 & -.892 \\
\hline $\begin{array}{l}\text { A standard error } \\
\text { of asymmetry }\end{array}$ & .322 & .322 & .322 & .322 & .322 & .322 & .322 \\
\hline Measure flatness & -.634 & 1.503 & .389 & .768 & .966 & .070 & -.240 \\
\hline $\begin{array}{l}\text { A standard error } \\
\text { of flatness }\end{array}$ & .634 & .634 & .634 & .634 & .634 & .634 & .634 \\
\hline Minimum & 3.00 & 1.00 & 2.00 & 1.00 & 1.00 & 1.00 & 2.00 \\
\hline Maximum & 5.00 & 5.00 & 5.00 & 5.00 & 5.00 & 5.00 & 5.00 \\
\hline
\end{tabular}

Table 5. Descriptive statistics for P19-P22

\begin{tabular}{|c|c|c|c|c|c|c|c|}
\hline & P19 & $\mathrm{O} 20$ & $\mathrm{P} 20$ & $\mathrm{O} 21$ & $\mathrm{P} 21$ & $\mathrm{O} 22$ & $\mathrm{P} 22$ \\
\hline Mean & 4.0182 & 4.4545 & 3.9818 & 4.6000 & 4.0182 & 4.5818 & 4.3818 \\
\hline Median & 4.0000 & 5.0000 & 4.0000 & 5.0000 & 4.0000 & 5.0000 & 5.0000 \\
\hline Mode & 4.00 & 5.00 & 4.00 & 5.00 & 4.00 & 5.00 & 5.00 \\
\hline Std. deviation & .89217 & .81236 & .80487 & .70972 & .95240 & .91674 & .95240 \\
\hline Rate asymmetry & -.686 & -1.891 & -1.072 & -1.819 & -.705 & -2.795 & -1.783 \\
\hline $\begin{array}{l}\text { A standard error } \\
\text { of asymmetry }\end{array}$ & .322 & .322 & .322 & .322 & .322 & .322 & .322 \\
\hline Measure flatness & -.144 & 4.828 & 2.587 & 2.889 & -.377 & 8.028 & 2.949 \\
\hline $\begin{array}{l}\text { A standard error } \\
\text { of flatness }\end{array}$ & .634 & .634 & .634 & .634 & .634 & .634 & .634 \\
\hline Minimum & 2.00 & 1.00 & 1.00 & 2.00 & 2.00 & 1.00 & 1.00 \\
\hline Maximum & 5.00 & 5.00 & 5.00 & 5.00 & 5.00 & 5.00 & 5.00 \\
\hline
\end{tabular}

Source: Author's research

Furthermore, if we analyze the relationship between men and women, and foreign and domestic tourists, in terms of reliability and sensitivity, the results are as in the table below.

Table 6. T-Test for independent samples for tangibles and reliability

\begin{tabular}{cccccc}
\hline \multirow{2}{*}{ GENDER } & \multicolumn{1}{c}{$\begin{array}{c}\text { Tangibles } \\
\mathrm{M} \pm \mathrm{SD}\end{array}$} & $\begin{array}{c}\text { Reliability } \\
\mathrm{M} \pm \mathrm{SD}\end{array}$ & t-test & $\mathrm{P}$ \\
\cline { 2 - 6 } & Male & $4,24 \pm 0,97$ & $4,09 \pm 0,95$ & $-2,173$ & 0,030 \\
\hline \multirow{2}{*}{ TOURISTS } & Demale & $4,34 \pm 0,83$ & $3,97 \pm 0,87$ & $-6,836$ & 0,021 \\
\cline { 2 - 6 } & Fomestic & $4,27 \pm 0,93$ & $4,04 \pm 0,92$ & 5,912 & 0,018 \\
\hline
\end{tabular}

Source: Author's research 
As the $\mathrm{p}<0.05 \mathrm{Ho}$ is accepted with probability of $95 \%$ and $99 \%$, i.e. we can say that there are no statistically significant differences between tangibility and reliability in men, women, local and foreign tourists.

Research shows that in the process of communication, no matter if it is verbal or nonverbal, in all segments of consumers of their services, hoteliers and restaurateurs, special attention should be drawn to the satisfactory achievement of the atmosphere, the employee attitude in terms of interaction with guests, achieving results of the first-impression, acceptance and resolution of complaints, respect for the principles of social structure and communication in after-sales phase, or "accompaniment" guests.

\section{CONCLUSION}

There has been growing demand to understand and identify services quality as the most important performance of the business policy in catering and hotel industry, and measuring the quality gets more and more important in the services marketing. Determining the strategy of service quality is directly related to the concept of consumer satisfaction. Delivering exceptional service, superior value, is the most effective way to achieve competitive advantage through implementation of adequate satisfaction ratings. Defining customer satisfaction in the creation and delivery of services on presentation, a modified model showed the station deviations from the expected and experienced quality of service. The research results showed that the method and procedure of communication with guests in many ways determines the level of satisfaction. Communication becomes an essential element of quality assessment services. This means that the hotel and catering enterprise communication processes can reduce or eliminate the gap between the expected and achieved satisfaction ratings. Anticipating the needs of consumers and service creation belongs to the past or the present time, with delivery in this regard relates to the future, where communication factors can contribute to increasing the value.

The aim of this paper was to evaluate the expectations and perceptions of guests in a tourist complex Palić. This and similar studies should be carried out continuously and at tourism destinations in individual tourism sector institutions. The need for consumers of tourism services is not a static category, and is not offered by the competition, and self-assessment is a good guideline for building a strategic approach to guests.

\section{REFERENCES}

Bateson, J.E.G., \& Douglas H.K. (2012). Marketing usluga. Beograd: Data Status.

Choi, T.Y., \& Chu, R. (2001). Determinants of hotel guests' satisfaction and repeat patronage in the Hong Kong hotel industry. International Journal of Hospitality Management, 20(3), 277-297. doi:10.1016/ S0278-4319(01)00006-8

Ćosić, M. (2007). Upravljanje kvalitetom turističkih usluga. Beograd: Visoka turistička škola.

Gundersen, M. G., Heide, M., \& Olsson, U. H. (1996). Hotel Guest satisfaction among Business Travellers: What Are the Important Factors? The Cornell Hotel and Restaurant Administration Quarterly, 37(2), 72-81. doi:10.1016/0010-8804(96)83104-1

Kosar, L., \& Rašeta, S. (2005). Challenges of Quality. Belgrade: The College of Hotel Management.

Kotler, P., \& Keller, K.L. (2009). Marketing management. Upper Saddle River, NJ: Pearson Prentice Hall.

Moutinho, L. (2005). Strateški menadžment u turizmu. Zagreb: Masmedia.

Parasuraman, A., Zeithaml V.A., \& Berry L. (1985). A conceptual model of service quality and its implications for future research. Journal of Marketing, 49(4), 41-50. doi:10.2307/1251430

Porter, M.E. (2007). Konkurentska prednost. Novi Sad: ASEE.

Stephens, P.A., Buskirk, S.W., Hayward, G.D., \& Martinez del Rio, C. (2005). Information theory and hypothesis testing: a cal for pluralism. Journal of Applied Ecology, 42(1), 4-12. doi:10.1111/j.13652664.2005.01002.x

Zeithaml, V.A., \& Bitner, M.J. (2003). Service marketing: Integrating customer focus across the firm. New York: McGraw-Hill. 